\title{
Tip 1 Diyabetli Çocuk ve Adölesanların Beslenme Sorunlarına Yaklaşım ve Yetişkin Kliniğe Devri
}

\author{
Approach to Nutritional Problems of Children and Adolescents with Type 1 Diabetes Mellitus \\ and Transition from to Adult Services
}

\section{Yasemin Atik Altınok ${ }^{1}$}

Geliş tarihi/Received: 10.09.2019 • Kabul tarihi/Accepted: 07.11.2019

\section{ÖZET}

Tip 1 Diabetes Mellitus (T1D)'da tıbbi beslenme tedavisi, diyabet bakımı ve eğitiminin temel bileşenlerinden biridir. Tip 1 diyabetli çocuk ve adölesanların tıbbi beslenme tedavisi, optimal glisemik kontrol ile birlikte büyüme-gelişmenin devamını sağlamayı ve diyabetliyi akut, kronik komplikasyonlardan korumayı amaçlar. T1D’li çocuk ve adölesanlara beslenme hakkında verilen öneriler tamamen sağlıklı beslenme kuralları çerçevesinde oluşturulur ve temel amacı çocuğun büyüme/ gelişmesinin devamını sağlamaktır. Diyabetli çocuk ve adölesanların beslenme tedavisinde ve eğitiminde karşılaşılan zorluklar genelde yaşla ilişkilidir ve farklı yaş gruplarının beslenme ve gelişim ihtiyaçlarını yansıtmaktadır. Bu nedenle, beslenme tedavisi yapılırken farklı yaş gruplarının belirleyici özellikleri mutlaka göz önünde bulundurulmalıdır. Bu makalede, okul öncesi dönem ve adölesan dönemdeki diyabetli bireylerin beslenme ile ilişkili sorunları ve diyabetli gençlerin erişkin kliniğine devri üzerinde durulacaktır.

Anahtar kelimeler: Tip 1 diyabet, çocuk, adölesan

\begin{abstract}
Medical nutrition therapy of Type 1 Diabetes Mellitus (T1D) is one of the main components of diabetes care and education. Medical nutrition therapy aims to maintain growth and development with optimal glycemic control and to protect diabetics from acute, chronic complications in children and adolescents with type 1 diabetics. Dietary recommendations for children and adolescents with T1D are based on healthy eating recommendations suitable for all children and the main aim is to ensure to growth and development of the child. Difficulties in nutrition therapy and education of children and adolescents with T1D are generally associated with age and reflect the nutritional and developmental needs of different age groups. Therefore, the characteristics of different age groups should be considered in nutritional therapy. This article will focus on the problems related to nutrition in preschool and adolescent diabetics and on the transfer to the adult clinic of young people with diabetes.
\end{abstract}

Keywords: Type 1 diabetes, child, adolescent

1. İletişim/Correspondence: Ege Üniversitesi, Tıp Fakültesi Hastanesi, Pediatrik Endokrin ve Diyabet Bilim Dalı, İzmir, Türkiye

E-posta: yasemin.atik@ege.edu.tr • @ https://orcid.org/0000-0001-5851-1012 


\section{GíRiş}

Tip 1 Diabetes Mellitus'ta (T1D) tıbbi beslenme tedavisi, diyabet bakımı ve eğitiminin temel bileşenlerinden biridir. T1D’li çocuk ve adölesanlara beslenme hakkında verilen öneriler tamamen sağlıklı beslenme kuralları çerçevesinde oluşturulur ve temel amacı çocuğun büyüme/gelişmesinin devamını sağlayacak kadar makro ve mikro besin ögesi ihtiyacını karşılamak, bireysel, kültürel tercihleri ve yaşam stiline göre beslenme gereksinimlerini saptamak ve optimal metabolik sonuçları sağlayarak makro ve mikro komplikasyonların oluşumunu önlemek ve geciktirmektir. Bireyselleştirilmiş beslenme planı ile uygulanan prandiyal insülin doz ayarlamaları metabolik kontrolü iyileştirir (1).

Diyabetli çocuk ve adölesanların beslenme tedavisinde ve eğitiminde karşılaşlan zorluklar genelde yaş ile ilişkilidir. Bu nedenle, bireysel beslenme tedavisi yapılandırılırken farklı yaş gruplarının beslenme ve gelişim ihtiyaçları mutlaka göz önünde bulundurulmalıdır (2). Genel olarak çocukluk çağında diyabet uzun gece uykuları, öngörülemeyen fiziksel aktiviteler ve yeme davranışları, sık geçirilen infeksiyon hastalıkları; adölesan çağda ise değişen insülin ihtiyacı, fizyolojik insülin direnci, değişken metabolik kontrol, tedaviye uyumsuzluk, beden imajı ile ilgili endişeler, riskli davranışlar nedeniyle yetişkin diyabetinden farklıdır $(1,2)$. Bu makalede, okul öncesi dönem ve adölesan dönemdeki diyabetli bireylerin beslenme ile ilişkili sorunları ve diyabetli gençlerin erişkin kliniğine devri üzerinde durulacaktır.

\section{Okul Öncesi Dönemde Sıklıkla Karşılaşılan Beslenme ile İlişkili Sorunlar}

Okul öncesi dönemdeki diyabetli çocuklar, diyabet bakımının tüm yönleriyle (insülin uygulaması, kan glukoz monitorizasyonu, öğün zamanları, besin seçimi gibi) bakımından sorumlu kişilere bağımlıdırlar. Okul öncesi dönemdeki T1D’li çocuğun diyabet bakımı, birincil olarak ebeveynleri olmak üzere tedavisini yapan diyabet ekibi, okulda ve/veya evde bakım veren bireyler ve diğer aile fertleri için sürekli zorluk içerir.
$\mathrm{Bu}$ yaş grubundaki çocuklar için optimal glisemik kontrolün sağlanabilmesi genellikle diyabetli daha büyük çocuklar ve adölesanlardan farklı yaklaşımlar gerektirir. Erken çocukluk dönemindeki yaşam tarzı seçimleri ve besin tercihleri, çocuğun yaşamı boyunca sürdüreceği sağlıklı alışkanlıkları edinmesi için bir firsat penceresi sunmaktadır. Diyabet ekibi, aile temelli bir yaklaşım ve yeterli eğitim ile çocuğun yaşam tarzı değişikliklerini desteklemelidir (3).

Değişken/tutarsız iştah, geçici besin tercihleri ve besin reddi genellikle diyabetlinin ebeveynleri ve bakıcıları için yemek zamanlarını zorlaştırır. Bunun yanı sıra gündüz bakım verenlerin (bakıcı, kreş görevlileri, büyükanne, büyükbaba, gibi) diyabette beslenme tedavisi hakkında bilgi düzeyinin yetersizliği nedeniyle, öğünde alınacak karbonhidrat miktarını belirleme becerisinde eksiklik, bakımdan sorumlu kişi ve/veya ebeveynlerin hipoglisemi korkusu; çocuğun gün boyunca devamlı beslenmesine, postprandiyal insülin uygulamalarına ve uzamış hiperglisemi periyotlarina neden olur (3).

Aile merkezli öğün zamanları sağlıklı yeme davranışları oluşturulmasında, çocuğun gün boyunca devamlı beslenmenin önlenmesinde, yeni besinlerin tüketiminin desteklenmesinde önemlidir ve glisemik kontrolü iyileştirerek kardiyovasküler hastalık riskini azaltır (3). Yoğun insülin tedavisi alan çocuklarda karbonhidrat sayımı diyabetin başlangıcında aileye öğretilmelidir (1).

Okul öncesi dönemdeki T1D’lilerin prandiyal insülin doz uygulama zamanı önemlidir. Küçük çocuklar için yemek yeme süresi yaklaşık 20 dakika ile sınırlandırılmalıdır (4). Bell et al. tarafından (5), çok sayıda araştırmayı değerlendirdikleri bir derlemede, preprandial bolus insülinin, öğün sırasında veya sonrasinda uygulanan insüline tercih edilmesi ve tüm okul öncesi çocuklar için rutin olarak tavsiye edilmesi gerektiği bildirilmiştir. Bununla birlikte, tutarsız miktarlarda besin tüketen çocuklarda veya çocuğa yeni yiyecekler sunulduğunda bolus 
insülin dozu yemek öncesinde ve yemek sırasında olmak üzere ikiye bölünebilir (5). Ögün sırasında verilen insülin dozu, ebeveynin çocuğun daha önce tükettiği besin miktarı ve çocuğun kalan iştahını göz önünde bulundurarak, çocuğun kalan yemeği de tüketeceğini öngörmesine dayanabilir. Hesaplamalarda 5-7 g karbonhidrata kadar olan küçük hatalar genellikle sorun oluşturmazken; daha büyük yanlışlıklar, yemekten 2-3 saat sonra hipoglisemi veya hiperglisemiye yol açabilir $(6,7)$ ve hipoglisemi oluştuğunda ek karbonhidrat tüketimi veya hiperglisemi oluştuğunda insülin düzeltme dozu uygulaması ile kontrol altına alınabilir (3). İnsülin infüzyon pompa tedavisi kullanan diyabetli çocuklarda ikili bolus uygulaması yapılarak öğün için uygulanacak insülin dozu yemekten önce ve 20-40 dakika sonra olmak üzere ikiye bölünür. Eğer çocuk yemeğini bitirmeden besin tüketimini bırakırsa ikinci bolus iptal edilmelidir (3).

T1D’li çocuklarda karbonhidratın aşırı kısıtlanması büyüme üzerinde istenmeyen etkilere neden olabileceğinden önerilmemektedir. Okul öncesi çağdaki diyabetliler günlük enerji ihtiyacının \%4555’ini karbonhidratlardan karşılamalıdır (1). Yapılan çalışmalarda, T1D’li okul öncesi çağdaki çocukların diyet kalitelerinin sağlıklı yaşıtlarından kötü olduğunu ve yaşıtlarından daha az sebze ve meyve, daha fazla doymuş yağ tükettiklerini göstermektedir $(8,9)$. Çocuklarda küçük yaşta oluşan beslenme alışkanlıkları ileri yaşlardaki besin seçimlerini etkiler, bu nedenle erken dönemde diyabetli çocuğun sebze ve meyve tüketimini artırmak ve doymuş yağ asidi tüketimini azaltmak konusunda aile bireyleri teşvik edilmeli ve bu konuda gerekli girişimler yapılmalıdır (10). Okul öncesi dönemdeki diyabetlilerin tıpkı sağlıklı yaşıtları gibi bir besini reddettiğine karar vermeden önce en az 10 defa o besine maruziyeti gereklidir (11).

Yapılan çalışmalarda T1D’li çocukların genel popülasyona göre daha çok fazla kilolu olduğunu bildirilmektedir $(12,13)$. Bu nedenle, aşırı vücut ağırlık kazanımını belirlemek amacıyla, boy uzunluğu ve boy uzunluğuna göre vücut ağırlığı değerlendirmelerini içeren büyüme grafikleri önemlidir. Böylece tüm ailenin dahil olacağı beslenme müdahalelerine zamanında başlanabilir. Hem diyet kalitesini hem de sosyal etkileşimi iyileştirmek için aile ile birlikte yenilen öğünler teşvik edilmeli ve çocuğun ev, kreş, anaokulu gibi çevresinde sağlıklı besine ulaşabileceği ortamlar sağlanmalıdır $(3,14)$.

\section{Adölesan Dönemde Sıklıkla Karşılaşılan Beslenme ile İlişkili Sorunlar}

Adölesan dönem, pubertenin biyolojik ve psikolojik değişimlerini içerisinde barındıran çocukluk çağı ile yetişkinlik çağı arasındaki geçiş dönemidir. T1D’linin adölesan dönemi, diyabetli birey, aile ve diyabet ekibi için ek sorunlar ile karakterizedir. Adölesanların büyük çoğunluğu, bu dönemin zorluklarına uyum sağlamış olsa da adölesan diyabetlinin sağlık bakımı ve duygusal ihtiyaçlarının daha küçük ve yetişkin diyabetlilerden belirgin bir şekilde farklı olduğu kabul edilmelidir. T1D’li adölesanların çoğu düzensiz beslenme ve egzersiz yaklaşımları, insülin tedavisine uyumsuzluk, yeme davranış bozukluğu ve fizyolojik insülin direnci ile ilişkilendirilen kötü metabolik kontrole sahiptirler (15).

Adölesan dönemde vücut ağırlığında ve adipoz dokuda meydana gelen artış, vücut imajı hoşnutsuzluğuna neden olarak özellikle kızlarda yeme bozukluğu prevalansını artırır (16). Özellikle kitle iletişim araçlarında zayıflığın güzellikle eşdeğer olarak sunulmasıyla eş zamanlı olarak bu bozuklukların görülme sıklığı da artmıştır. Yapılan çalışmalar, T1D’in bozulmuş yeme davranışı oluşumunda risk faktörü olduğunu ortaya koymuştur $(17,18)$. Çalışmaların çoğu adölesan kızlara odaklanmışsa da bazı araştırmalar T1D’liadölesan erkeklerin de bozulmuşyeme davranışı riskinin artmış olabileceğini düşündürmektedir (19). Bozulmuş yeme davranışlarının etiyolojisi kompleks ve multifaktöryeldir; bireysel, ailesel ve sosyokültürel etkenler, bozulmuş yeme davranışı gelişmesine katkıda bulunabilir $(20,21)$.

T1D’linin vücut ağırlığını azaltmak amacıyla tekrarlayan insülin doz kısıtlaması/atlaması diyabete 
özgü yeme davranışı bozukluğudur. Diyabetli öğün yada öğün harici zamanlarda insülin dozu atlama ve/veya kısıtlaması yaptığında, postprandiyal hiperglisemi, ketonemi, osmotik diürez, glikozüri, ketonüri ve dehidratasyon oluşur. $\mathrm{Bu}$ durum, besinlerden elde edilen enerjinin idrar yoluyla atımını sağlayarak vücut ağırlık kaybına katkıda bulunur. T1D'e eşlik eden ve insülin doz atlama ve/veya kısıtlaması ile karakterize yeme davranış bozukluğunun tekrarlayan diabetik ketoasidoz ve şiddetli hipoglisemi atakları, kötü metabolik kontrol, makro ve mikro komplikasyon gelişimi ile ilişkili olduğu ve morbidite ve mortaliteyi dramatik biçimde arttırdığı bildirilmektedir (18,22,23).

T1D izleminde, yeme davranış bozukluğunun erken fark edilmesi ve tedavisi potansiyel zararlı etkilerini önleyebilmekaçısındanönemlidir.Diyabeteözgüyeme bozukluğu tarama ölçekleri ve yapılandırılmış klinik görüşmeler genç diyabetlilerde yeme bozukluğunu tespit etmede yardımcı olur (1). Özellikle hedef kan şekerlerine ulaşamayan, açıklanamayan vücut ağırlık kaybı ve metabolik kontrolde bozulma olan adölesan diyabetliler bu bakımdan değerlendirilmelidir (24). Uluslararası Çocuk ve Adölesan Diyabet Derneği (International Society of Pediatric and Adolescents Diabetes [ISPAD])'nin 2018 uzlaşı raporunda, 16 sorudan oluşan ve diyabetlinin kendi kendine 10 dakikadan az bir sürede cevaplayabileceği Diabetes Eating Problem Survey-Revised'in (DEPS-R) rutin klinik değerlendirmede kullanılması önerilmiştir (1). Atik Altınok ve arkadaşları (25) tarafından DEPS-R'nin Türkçe versiyonunun geçerlilik güvenilirlik çalışması 9-18 yaş aralığındaki 200 T1D’li ile yapılmış kızların \%29.1'inde ve erkeklerin \%17.8'inde bozulmuş yeme davranışı riski tespit edilmiş, cinsiyetler arasında istatistiksel önemli fark bulunmamıştır.

\section{Düşük Karbonhidrat, Yüksek Yağ ve Yüksek Protein Alımı}

Diyabet yönetiminde birincil amaç kan şekerini normal veya normale yakın düzeylerde tutmak olduğundan çok sayıda diyabetlinin kafasını en çok meşgul eden soru 'tüketilen besinin kan şekerini nasıl etkilediği?'dir. Yapılan çalışmalar sonucunda elde edilen bulgular, T1D’li adölesanların sağlıklı beslenme konusunda genel bir anlayışa sahip olduklarını ve sağlıklı yaşıtları gibi içinde bulundukları çevrede sağlıksız besinlere maruziyetlerinin yüksek olduğunu göstermektedir. Akranları ile etkileşimleri de gençlerin sağlıksız besinlere maruziyeti ve bunları tüketme konusundaki sosyal baskıyı artırmaktadır. Bununla birlikte, diyabetli olmak bazen sağlıklı beslenme anlayışını olumsuz yönde etkileyebilir. Diyabetli çocuk ve adölesanların günlük enerji ihtiyaçlarının \%30-35'inin yağlardan ( $<\% 10$ doymuş yağ + trans yağ asidi) sağlanması önerilmektedir (1). Bununla birlikte yapılan çalışmalarda, diyabetli adölesanların önerilerin üzerinde yağ ve doymuş yağ asidi tükettikleri bildirilmiştir (25-27). Gellar et al. (28) tarafından yapılan bir araştırmada T1D’li adölesanlar 'sağlıklı beslenme’yi düşük karbonhidratlı yiyecekler, sebzeler, az yağlı yiyecekler tüketmek olarak; 'serbest besin’ leri ise karbonhidrat sayımında sayılmayacak olanlar olarak tanımlamışlar ve diyabet yönetimi için iyi olduğu bildirilen serbest besin örneklerinin çoğunu peynir, et ve jambon gibi karbonhidrat içermeyen ancak protein ve doymuş yağ içeriği yüksek besinler oluşturmuştur. Yüksek yağ alımı, artmış fazla kiloluluk ve obezite riski ile ilişkili iken, yüksek doymuş ve trans yağ alımı artmış kardiyovasküler hastalık riski ile ilişkilidir (29). Bu nedenle klinik uygulamada diyette yağ alımı ile ilgili temel amaç, doymuş yağ, trans yağ asidi ve toplam yağ alımının önerileri aşmamasını sağlamaktır. Amerikan Kalp Derneği (The American Heart Association [AHA]), çocukların daha sonraki yaşamda kardiyovasküler hastalık riskini azaltmak için doymuş yağları sınırlandırılmış ve doymuş yağların yerini tekli doymamış ve çoklu doymamış yağların aldığı sağlıklı bir diyeti desteklemektedir (29).

Son yllarda T1D tedavisi için düşük karbonhidratlı diyetler, sosyal medya tarafindan popüler hale getirilmiştir. Özellikle karbonhidrat sayımı uygulamalarının yaygınlaşması ile diyabetliler arasında düşük karbonhidratlı besin tüketimi eğilimi artmıştır. Düşük karbonhidratlı diyetler 
aynı zamanda ağırlık kontrolü için de moda haline gelmiştir ve popüler televizyon, kitap, dergi ve kişisel internet blogları gibi ortamlarda "sağlıklı" olarak yansıtılmaktadır. Genel olarak, bu tür paylaşımlar, "karbonhidrat tüketimi postprandiyal glisemik dalgalanmaya neden oluyorsa, düşük karbonhidrat alımı daha düşük glisemikyanıt oluşturur” sezgisinden yararlanır. Buna ek olarak daha az insülinin daha iyi olduğu fikri, aileler tarafindan yaygın olarak ifade edilmektedir. Oysaki T1D’li çocuk ve adölesanlarda karbonhidrat kısıtlaması büyüme hızında azalmaya, düşük enerji alımına ve yüksek riskli lipit profiline neden olabilir ve yeme bozukluğu gibi psikolojik hastalıklara zemin hazırlayabilir (1). Bunun yanı sıra düşük karbonhidrat alımı hipoglisemi riskini artırabilir veya glukagonun hipoglisemi tedavisindeki etkisine potansiyel olarak zarar verebilir (30). Düşük karbonhidratlı bir diyetin anlamı bireyler arasında farklılık gösterebileceğinden diyabetli çocuk/aile için ne anlama geldiğini anlamak önemlidir. $\mathrm{Bu}$ nedenle diyabetli çocuk ve adölesanların düşük karbonhidrat alımı diyabet diyetisyeni ve diyabet ekibinin diğer üyeleri tarafından dikkatle ele alınmalı, ailenin karbonhidrat kısitlama nedenleri saygiyla araştırılmalıdır (1). Eğer diyabetli ve ailesi rutin bir şekilde günlük enerji alımının karbonhidratlardan gelen kısmını \%40'ın altında tutuyorlarsa, pediatrik diyabet diyetisyeni tarafından besin tüketim kayıtları özellikle kalsiyum, B grubu vitaminleri, demir ve posa alımı bakımından değerlendirilmeli ve gereken eklemeler yapılmalıdır (31). Yoğun insülin tedavisi alan çocuk ve adölesan diyabetlilerle yapılan makro besin ögesi alımının incelendiği çalışmalarda düşük karbonhidrat alımı, kötü metabolik kontrol ile ilişkili bulunmuştur $(26,32)$. Diyabetli çocuk ve aileleri ile karbonhidratların neden olduğu postprandiyal glisemik dalgalanmaları en az indirmek için düşük glisemik indeks, düşük glisemik yük ve günlük posa alımının artırılması konularında bilgilendirilmelidir.

Düşük karbonhidrat tüketimi ile birlikte artan protein ve yağ alımı veya bir ögünde protein ve yağ içeriği yüksek, yüksek enerjili besin tüketimi; yağların mide boşalmasını geciktirmesi, öğün sonrası kana geçen serbest yağ asitlerinin insülin direncine neden olması, protein ve yağların kan şekeri oluşumuna katkıda bulunmasını sağlayarak uzamış hiperglisemi ile sonuçlanır $(33,34)$. Prandiyal insülin doz hesaplamaları tipik olarak öğünde tüketilecek karbonhidrat miktarına uygun olarak, bireyselleştirilmiş Karbonhidrat/İnsülin oranı (K/I) kullanılarak yapılır. Bununla birlikte son yıllarda yapılan çalışmalarda, diyetle alınan yağ ve proteininin de uygulanacak insülin dozu ve veriliş şekline karar verilirken göz önünde bulundurulması gerektiğine dair kanıtlar artmaktadır $(35,36)$. Yüksek yağ ve yüksek protein içeren yüksek enerjili besin tüketimi sonrasında oluşan glisemik yanıtı önlemek konusunda karbonhidrat odaklı bolus dozu hesaplanma yöntemi sinırlı kalmaktadır. Bu nedenle yağ ve proteinlerin uzayan glisemik yanıtını kapatabilmek için insülinin etki edeceği sürenin uzatılması ve dozun artırılması gerekmektedir $(37,38)$. T1D’li çocuk ve adölesanın bazal insülin dozu, K/I ve karbonhidrat sayımı becerisi optimize edildikten sonra yapılacak olan bu tür müdahaleler, diyabetlinin besin tüketim kayıtları ve postprandiyal glukoz değerleri göz önünde bulundurularak bireyselleştirilmelidir. $\mathrm{Bu}$ tür yaklaşımlarda ilk önce postprandiyal hiperglisemiye neden olan besinlerin tanımlanarak, sorun yaratan besinlerin düşük yağ ve düşük proteinli alternatifleri konusunda diyabetli çocuk, adölesana ve aileye beslenme danışmanlığı verilmelidir (39).

\section{Diyabetli Adölesanın Erişkin Kliniğine Geçiş Evresi}

Çocukluktan erişkinliğe geçiş evresinin ilk döneminde (18-21 yaş) genç diyabetliler akademik, sosyal, ekonomik öncelikler ile diyabet bakımı arasında bir sıkışmışlık yaşamakta ve zorlukları aşma konusunda kendine güvensizlik hissetmektedir. Artan kişisel bakım sorumluluğunu üstlenmenin yanı sıra, genç yetişkinliğe giden adölesanların sonunda pediatri kliniklerinden, yetişkin diyabet kliniklerine geçmeleri gerekecektir. Yirmili yaşların sonlarına doğru gençlerin gelişim aşaması "gelişmekte olan yetişkinlik" olarak tanımlanmıştır ve bu dönem önemli bir eğitim, sosyal, iş ve finansal öncelikler dönemi olmasıyla 
karakterizedir. $\mathrm{Bu}$ süreçte yaşamda öncelikleri farklılaşmış, ebeveyn desteği azalmış ve diyabet bakımınauyumuazalmışgenç diyabetlilerin metabolik kontrolü kötüleşebilir ve akut komplikasyonların yanı sıra kronik mikrovasküler komplikasyonlar ve erken mortalite açısından risk altındadırlar (15). Yetişkin kliniğine geçiş kavramı 'adölesan veya genç erişkin diyabetli bireyin (ve ailesinin) çocuk odaklı bir sağlık sisteminden, yetişkin odaklı sağlık sistemine geçişi amacıyla yapılan planlı bir süreci ifade eder (40). Diyabetli adölesanın erişkin kliniğine geçiş evresi zorlukları arasında; geçiş hazırlıklarındaki eksiklikler, pediatri kliniğinden erişkin kliniğine geçişten sonra diyabet kontrollerinden kopma ve geçiş sonrası diyabetle ilişkili hastane yatışlarında artış yer almaktadır (15). Diyabetli gencin erişkin kliniğine devri yapılırken, pediatri kliniğinde izlemi sırasında beslenme tedavisine uyumu, sağlıksız besin tercihleri, karbonhidrat sayımı becerisi, bozulmuş yeme davranışı varlığı, insülin dozu kısıtlaması/ atlaması yapma durumu gibi konularda erişkin kliniğine ayrıntılı bilgi verilmelidir.

\section{SONUÇ VE ÖNERİLER}

Tip 1 diyabetli çocuk ve adölesanların tıbbi beslenme tedavisi, optimal glisemik kontrol ile birlikte büyümegelişmenin devamını sağlamayı ve diyabetliyi akut, kronik komplikasyonlardan korumayı amaçlar. Büyüme ve gelişmenin ön planda olduğu, çocukluk döneminden adölesan döneme geçişi kapsayan süreç; büyüme hızındaki değişiklikler ile ilişkili iştah dalgalanmaları ve fizyolojik, psikolojik değişimler arasındaki ilişkinin derinlemesine anlaşlarak bireyselleştirilmiş tıbbi beslenme tedavisinin düzenlenmesini gerektirir.

Çıkar çatışması - Conflict of interest: Yazarlar çıkar çatışması olmadığını beyan ederler. - The authors declare that they have no conflict of interest.

\section{KAYNAKLAR}

1. Smart CE, Annan F, Higgins LA, Jelleryd E, Lopez M, Acerini CL. ISPAD Clinical Practice Consensus
Guidelines 2018:Nutritional management in children and adolescents with diabetes. Pediatr Diabetes. 2018;19:136-54.

2. Spiegel G. Nutrition Therapy for Youth with Diabetes. In: Evert AB, Franz MJ, Ed. American Diabetes Association Guide to Nutrition Therapy For Diabetes. 3rd edition. Arlington: American Diabetes Association; 2017:159-83.

3. Sundberg F, Barnard K, Cato A, Beaufort C, DiMeglio LA, Dooley $\mathrm{G}$ et al. Managing diabetes in preschool children. Pediatr Diabetes. 2017;0:1-19.

4. Adamson M, Morawska A, Wigginton B. Mealtime duration in problem and non-problem eaters. Appetite. 2015;84:228-34.

5. Bell KJ, Smart CE, Steil GM, Brand-Miller JC, King B, Wolpert HA. Impact of fat, protein, and glycemic index on postprandial glucose control in type 1 diabetes: implications for intensive diabetes management in the continuous glucose monitoring era. Diabetes Care. 2015;38:1008-15.

6. Smart CE, Ross K, Edge JA, Collins CE, Colyvas, King BR. Children and adolescents on intensive insulin therapy maintain postprandial glycaemic control without precise carbohydrate counting. Diabet Med. 2009;26:279-85.

7. Smart CE, King BR, McElduff P,Collins CE. In children using intensive insulin therapy, a 20-g variation in carbohydrate amount significantly impacts on postprandial glycaemia. Diabet Med. 2012;29:e21-e24.

8. Sundberg F, Augustsson M, Forsander G, Cederholm $\mathrm{U}$, Axelsen M. Children under the age of seven with diabetes are increasing their cardiovascular risk by their food choices. Acta Paediatr. 2014;103:404-10.

9. Patton SR, Dolan LM, Chen M, Powers SW. Dietary adherence and mealtime behaviors in young children with type 1 diabetes on intensive insulin therapy. J Acad Nutr Diet. 2013;113:258-62.

10. Kaikkonen JE, Mikkila V, Magnussen CG, Juonala M, Viikari JS, Raitakari OT. Does childhood nutrition influence adult cardiovascular disease risk? - insights from the Young Finns Study. Ann Med. 2013;45:120-8.

11. Cooke L. The importance of exposure for healthy eating in childhood: a review. J Hum Nutr Diet. 2007; 20:294301.

12. Mehta SN, Volkening LK, Quinn N, Laffel LMB. Intensively managed young children with type 1 diabetes consume high-fat, low-fiber diets similar to age-matched controls. Nutr Res. 2014;34:428-35.

13. DuBose SN, Hermann JM, Tamborlane WV, Beck RW, Dost A, DiMeglio LA, et al. Type 1 Diabetes Exchange Clinic Network and Diabetes Prospective Follow-up Registry. Obesity in youth with type 1 diabetes in Germany, Austria, and the United States. J Pediatr. 2015;167:62732. 
14. Lipsky LM, Nansel TR, Haynie DL, Mehta SN, Laffel LM. Associations of food preferences and household food availability with dietary intake and quality in youth with type 1 diabetes. Appetite. 2012;59(2):218-23.

15. Danne T, Phillip M, Buckingham BA, Jarosz-Chobot P, Saboo B, Urakami T, et al. ISPAD Clinical Practice Consensus Guidelines 2018 Diabetes in adolescence. Pediatr Diabetes. 2018;19(Supply. 27):250-61.

16. Meltzer LJ, Johnson SB, Prine JM, Banks RA, Desrosiers PM, Silverstein JH. Disordered eating, body mass, and glycemic control in adolescents with type 1 diabetes. Diabetes Care. 2001;24(4):678-82.

17. Mannucci E, Rotella F, Ricca V, Moretti S, Placidi GF, Rotella CM. Eating disorders in patients with type 1 diabetes: a meta-analysis. J Endocrinol Invest. 2005;28(5):417-419.

18. Jones JM, Lawson ML, Daneman D, Olmsted MP, Rodin G. Eating disorders in adolescent females with and without type 1 diabetes: cross sectional study. BMJ. 2000;320(7249):1563-66.

19. Svensson M, Engström I, Aman J. Higher drive for thinness in adolescent males with insulin-dependent diabetes mellitus compared with healthy controls. Acta Paediatr. 2003;92(1):114-7.

20. Dalle Grave R. Eating disorders: progress and challenges. Eur J Intern Med. 2011;22(2):153-60.

21. Colton P, Olmsted M, Daneman D, Rydall A, Rodin G. Disturbed eating behavior and eating disorders in preteen and early teenage girls with type 1 diabetes: a case-controlled study. Diabetes Care. 2004;27(7):1654-59.

22. Young V, Eiser C, Johnson B, Brierley S, Epton T, Elliott J, et al. Eating problems in adolescents with Type1 diabetes: A systematic review with meta-analysis. Diabet Med. 2013;30(2):189-98.

23. Peveler RC, Bryden KS, Neil HA, Fairburn CG, Mayou RA, Dunger DB, et al. The relationship of disordered eating habits and attitudes to clinical outcomes in young adult females with type 1 diabetes. Diabetes Care. 2005;28(1): 84-8.

24. Pinhas-Hamiel O, Hamiel U, Levy-Shraga Y. Eating disorders in adolescents with type 1 diabetes: Challenges in diagnosis and treatment. World J Diabetes. 2015;6(3):517-26.

25. Atik Altınok Y, Özgür S, Meseri R, Özen S, Darcan Ş, Gökşen D. Reliability and validity of the diabetes eating problem survey in Turkish children and adolescents with type 1 diabetes mellitus. J Clin Res Pediatr Endocrinol. 2017;9(4):323-8.

26. Katz ML, Mehta S, Nansel T, Quinn H, Lipsky LM, Laffel LM. Associations of nutrient intake with glycemic control in youth with type 1 diabetes: differences by insulin regimen. Diabetes Technol Ther. 2014;16(8):5128.

27. Rovner AJ, Nansel TR. Are children with type 1 diabetes consuming a healthful diet?: a review of the current evidence and strategies for dietary change. Diabetes Educ. 2009;35(1):97-107.

28. Gellar LA, Schrader K, Nansel TR. Healthy eating practices: perceptions, facilitators, and barriers among youth with diabetes. Diabetes Educ. 2007;33(4):671-9.

29. Sacks FM, Lichtenstein AH, Wu JHY, Appel LJ, Creager MA, Kris-Etherton PM, et al. American Heart Association. Dietary fats and cardiovascular disease: a presidential advisory from the American Heart Association. Circulation. 2017;136:e1-e23.

30. Ranjan A, Schmidt S, Damm-Frydenberg C, Steineck I, Clausen TR, Holst JJ, et al. Low-carbohydrate diet impairs the effect of glucagon in the treatment of insulin-induced mild hypoglycemia: A randomized crossover study. Diabetes Care. 2017;40(1):132-5.

31. de Bock M, Lobley K, Anderson D, Davis E, Donaghue K, Pappas M, et al. Endocrine and metabolic consequences due to restrictive carbohydrate diets in children with type 1 diabetes: An illustrative case series. Pediatr Diabetes. 2018;19(1):129-37.

32. Nansel TR, Lipsky LM, Liu A. Greater diet quality is associated with more optimal glycemic control in a longitudinal study of youth with type 1 diabetes. Am J Clin Nutr. 2016;104:81-87.

33. Lodefalk M, Åman J, Bang P. Effects of fat supplementation on glycaemic response and gastric emptying in adolescents with type 1 diabetes. Diabet Med. 2008;25(9):1030-1035.

34. Smart CEM, Evans M, O’Connell SM, McElduff P, Lopez $\mathrm{PE}$, Jones TW, et al. Both dietary protein and fat increase postprandial glucose excursions in childrenwith type 1 diabetes, and the effect is additive. Diabetes Care. 2013;36(12):3897-902.

35. Lee SW, Cao M, Sajid S, Hayes M, Choi L, Rother C, et al. The dual-wave bolus feature in continuous subcutaneous insulin infusuon pumps controls prolonged postprandial hyperglycaemia better than standard bolus type 1 Diabetes. 2004;17:211-6.

36. Campbell MD, Walker M, King D, Gonzalez JT, Allerton D, Stevenson EJ, et al. Carbohydrate counting at meal time followed by a small secondary postprandial bolus injection at 3 hours prevents late hyperglycemia, without hypoglycemia, after a high-carbohydrate, high-fat meal in type 1 diabetes. Diabetes Care. 2016;39(May):141-2.

37. Wolpert HA, Atakov-Castillo A, Smith SA, Steil GM. Dietary Fat Acutely Increases Glucose Concentrations and Insulin Requirements in PatientsWith Type1 Diabetes. Diabetes Care. 2013;36(April):810-6. 
38. Paterson M, Bell KJ, O’Connell SM, Smart CE, Shafat A, King B. The Role of Dietary Protein and Fat in Glycaemic Control in Type 1 Diabetes: Implications for Intensive Diabetes Management. Curr Diab Rep. 2015;15(9):61

39. Bell KJ, Smart CE, Steil GM, Brand-Miller JC, King B, Wolpert HA. Impact of fat, protein, and glycemic index on postprandial glucose control in type 1 diabetes: implications for intensive diabetes management in the continuous glucose monitoring era. Diabetes Care. 2015;38(6):1008-15.

40. Blum RWM, Garell D, Hodgman CH, Jorissen TW, Okinow NA, Orr DP, et al. Transition from child-centered to adult health-care systems for adolescents with chronic conditions. A position paper of the Society for Adolescent Medicine. J Adolesc Heal. 1993;14:570-6. 